\title{
Data Set: Odontometric Comparisons of Permanent Dentition in Human Populations
}

\author{
Hiroyuki Yamada* \\ Department of Anatomy, School of Dentistry, Aichi-Gakuin University, Nagoya, Japan
}

Mesiodistal and buccolingual tooth crown diameters constitute the most widely documented of anthropometric features. These two measurements provide significant information on the fields of human biological problems such as physical anthropology, oral biology, and orthodontics. In the past eighty years, odontometric data has brought a lot of benefit to anthropological and orthodontic research. Mizoguchi (1988) published a manuscript on the mesiodistal and buccolingual crown diameters of modern human populations worldwide, and Kieser (1990) wrote a book on human tooth size. However, after these publications, little else was done to document odontometric data from a global standpoint. The materials presented here summarize odontometric data from around the world. Additionally, data are presented on tooth agenesis.

I should be extremely happy to be of service to the researchers in dental anthropology as well as orthodontics.

\section{REFERENCES}

Kieser JA. 1990. Human Adult Odontometrics: The Study of Variation in Adult Tooth Size. Cambridge: Cambridge University Press.

Mizoguchi Y. (1988) A Statistical Analysis of Geographical Variation in Dental Size. A report of the Research Supported by a Grant-in-Aid for Scientific Research from the Ministry of Education, Science and Culture, Japan. Pp. 1-124.

The full dataset is published as an Excel spreadsheet online as Supplemental Information, and contains summary data based on the following references. This manuscript can be cited in reference to this dataset.
Points to be paid attention are as follows

Samples: population / group

Locality: place / district / site / nationality

Note: skull or cast/right side or left side/ comments etc.

Period - Appendix: period / era / date / comments etc.

Data Source: author

M-D Crown Diameters: mesiodistal crown diameters

B-L Crown Diameters: buccolingual crown diameters

$\mathrm{N}$ : number of sample / number of teeth

Mean: mean / average of both sides

SD: standard deviation

SE: standard error

$\mathrm{V}$ : variance

Modern Japanese: born from 1868 to 1945

Recent Japanese: born from 1945 to present

USA: United States of America

UK: United Kingdom

NZ: New Zealand

\section{REFERENCES}

Akiyama Y., Suzuki A, and Takahama Y. (1991) Tooth size of Japanese - General populations in Akita, Tanegashima, Tsushima, Okinawa and Taiwan-. The Journal of Japan Orthodontic Society, 50, 210-223. (In Japanese with English summary)

Alvesalo L. (1985) Dental growth in 47, XYY males and in conditions with other sex-chromosome anomalies. In, The Y chromosome, Part B, Clinical Aspects of $Y$ Chromosome Abnormalities. Alan R. Liss, New York. Pp. 277-300.

*Correspondence to:

Hiroyuki Yamada

Department of Anatomy

School of Dentistry

Aichi-Gakuin University

Nagoya, Japan

Email: ymd_20hiro4@yahoo.co.jp 
Aoyama T., Mastumoto K., Kobayasi T, and Mastuda T. (1957) The sexual variation of size in Japanese human teeth. Journal of Osaka Dental University, 20, 344-353. (In Japanese.)

Asakura M.(1975) Relationships of size and form of the remaining teeth to third molar agenesis. The Aichi-Gakuin Journal of Dental Science, 13, 270-302. (In Japanese with English summary.)

Axelsson G. and Kirveskari P. (1983) Crown size of permanent teeth in Icelanders. Acta Odontologica Scandinavica, 41, 181-186.

Bailit H.L., Dewitt、 S.J., and Leigh R.A. (1968) The size and morphology of the Nasioi dentition. American Journal of Physical Anthropology, 28, 271-287.

Barnes D.S. (1969) Tooth morphology and other aspects of the Teso dentition. American Journal of Physical Anthropology, 30, 183-194.

Barrett M.J., Brown T. and MacDonald M.R. (1963) Dental observations on Australian Aborigines, MD crown diameters of permanent teeth. Australian Dental Journal, 8, 150-156.

Baume B.J. and Coohen M.M. (1971) Studies on agenesis in the permanent dentition. American Journal of Physical Anthropology, 35, 125-128

Ben-David Y., Hershkovitz I., Rubin D., Moscona D., and Ring B. (1992) Inbreeding effects on tooth size, eruption age and fluctuating asymmetry among South Sinai Bedouins. In P. Smith and E. Tchernov (Eds.), Structure, function and evolution of teeth (pp. 361-389). Tel Aviv: Freund Publishing House.

Bhasin M.K., Sharma A., Singh I.P., and Walter, H. (1985) Morphological and metric dental study on Indians. Zeitschrift für Morphologie und Anthropologie, 76,77-90.

Boyd R.C.(1972) Appendix IV: An odontometric and observational assessment of the dentition. In R.A. Little wood (Ed.), Physical Anthropology of the Eastern Highlands of New Guinea. University of Washington Press, Seattle and London.

Brace C.L. (1976) Tooth reduction in the Orient. Asian Perspective, 19, 203-219.

Brace C.L. (1979) Krapina, "Classic" Neanderthals, and the evolution of the European face. Journal of Human Evolution, 8, 527-550.

Brace C.L. and Nagai M. (1982) Japanese tooth size, past and present American Journal of Physical Anthropology, 59, 399-411.

Brace C.L. and Vitzthum V. (1984a) Human tooth size at Mesolithic, Neolithic and Modern levels at Niah Cave, Sarawak: Comparisons with other Asian Populations. The Sarawak Museum Journal, 33, 7582.

Brace C.L., Shao X.-qing, and Zhang Z.-biao. (1984b) Prehistoric and modern tooth size in China. In F.H. Smith and F. Spencer (Eds), The Origins of
Modern Humans: A world Survey of the Fossil Evidence (485-516). New York: Alan R. Liss.

Brook A.H., Griffin R.C., Smith R.N., Townsend G.C., Kaur G., Davis G.R., and Fearne J. (2009) Tooth size patterns in patients with hypodontia and supernumerary teeth. Archives of Oral Biology, 54, 63 -70 (Supplement 1.)

Brown T. and Townsend G.C. (1979) Sex determination by single and multiple tooth measurements. Occasional Papers in Human Biology, 1, 1-16.

Brown T., Margetts B., and Townsend G.C. (1980) Comparison of MD crown diameters of the deciduous and permanent teeth in Australian Aborigines. Australian Dental Journal, 25, 28-33.

Brown P. (1987) Pleistocene homogeneity and Holocene size reduction: The Australian human skeletal evidence. Archaeology in Oceania, 22:41-67.

Cadien (1972) Dental Variation in Man. In, S.L. Washburn and P. Dohinow (Eds.), Perspectives on human evolution (199-222). New York: Holt, Rinehart, and Winston.

Calcagno J.M. (1986) Dental reduction in PostPleistocene Nubia. American Journal of Physical Anthropology, 70, 349-363.

Campbell T.D. (1925) Dentition and palate of the Australian Aboriginal. University of Adelaide, The Hassell Press, 4-26.

Chamla M.C. (1980) Ètude des variations métriques des couronnes dentaires des Nord-Africains, de L' Èpipaléolithique a l' époque actuelle. L'Anthropologie (Paris), 84,2 54-271.

Cho D. (1973) Studies on the tooth size of Koreans. Journal of Growth, 12, 1-18. (In Japanese with English summary.)

Christensen H.C. and Melsen B. (1974) Relationship between tooth size and third molar agenesis. Scandinavia Journal of Dental Research, 82, 552-556.

Christensen A.F. (1998) Odontometric microevolution in the Valley of Oaxaca, Mexico. Journal of Human Evolution, 34, 333-360.

Clinch L.M. (1960) A longitudinal study of the mesiodistal crown diameters of the deciduous teeth and their permanent successors. European Journal of Orthodontics, 29, 75-81.

Coppa A., Cucina A., Mancinelli D., Vargiu R., and Calcagno J.M. (1998) Dental anthropology of Central-Southern, Iron age Italy, The evidence of metric versus nonmetric traits. American Journal of Physical Anthropology, 107, 371-386.

Cruz L.C. (1971) A study of the mesiodistal crown diameters of permanent teeth among young Filipino adults. The Journal of the Philippine Dental Association, 23, 14-18.

Dahlberg A.A. (1960) The dentition of the first agriculturists (Jarmo, Iraq). American Journal of Physical Anthropology, 18, 243-256. 
Dennison J. (1979) Tooth size and sexual dimorphism in prehistoric New Zealand Polynesian teeth. Archaeology and Physical Anthropology in Oceania, 14, 123-128.

Doran G.A. and Freedman L. (1974) Metrical features of the dentition and arches of populations from Goroka and Lufa. Papua New Guinea. $\mathrm{Hu}$ man Biology, 46, 583-594.

Doris J.M., Bernard B.W., and Kuftinec M.M. (1981) A biometric study of tooth size and dental crowding. American Journal of Orthodontics, 79, 326-336.

Drennan M.R. (1929) The dentition of a Bushman tribe. Annals of the South African Museum, 24, 6187.

Dutta P.C. (1983) An odontometric analysis of molar crown characters of Bronze Age Harappans. Anthropologischer Anzeiger, 41, 67-72.

Ebeling C.F., Ingervall B., Hedegard B., Hedegård B., and Lewin T. (1973) Secular changes in tooth size in Swedish men. Acta Odontologishe Scandinavia, 31, 141-147.

Forsberg C.M. (1992) Tooth size, spacing, and crowding in relation to erupting or impaction of third molars. American Journal of Orthodontics and Dentofacial Orthopedics, 2, 57-62.

Frayer D.W. (1977) Metric dental change in the European Upper Paleolithic and Mesolithic. American Journal of Physical Anthropology, 46, 109-120.

Freedman L. and Lofgren M. (1981) Odontometrics of Western Australian Aborigines. Archaeology in Oceania, 16, 87-93.

Gabriel A. (1955) The correlation of the size of human teeth with one another and with certain jaw measurements. The Dental Journal of Australia, 27, 174-186.

Garn S.M., Lewis A.B., and Kerewsky R.S. (1964) Sex difference in tooth size. Journal of Dental Research. 43, 306

Garn S.M., Lewis A.B., Swindler D.R., and Kerewsky R.S. (1967) Genetic control of sexual dimorphism in tooth size. Journal of Dental Research, 46, 963972. (Supplement to No.5).

Garn S.M., Lewis A.B., and Walenga A.L. (1968) Maximum-confidence values for the human mesiodistal crown dimension of human teeth. Archives Oral Biology, 13, 841-844.

Garn S.M., Osborne R.H., and McCabe K.D. (1979) The effect of prenatal factors on crown dimensions. American Journal of Physical Anthropology, 51, 665678.

Ghose L.J. and Bahdady V.S. (1979) Analysis of the Iraqi dentition, mesiodistal diameters of permanent teeth. Journal of Dental Research, 58, 10471054.

Gonda K. (1959) On the sexual differences in the dimensions of the human teeth. Journal of the An- thropological Society of Nippon, 67, 151-163. (In Japanese with English summary.)

Goose D.H. (1963) Dental measurement: An assessment of its value in anthropological studies. In, D.R. Brothwell (Ed.), Dental Anthropology (pp. 125 -148). New York: Pergamon.

Goose D.H. (1967) Preliminary study of tooth size in Families. Journal of Dental Research, 5, 959-962. (Supplement).

Green D.L. and Ewing G.H. (1955) Dentition of a Mesolithic Population from Wadi Halfa, Sudan. American Journal of Physical Anthropology, 27, 41-56.

Gungor A.Y. and Turkkahraman H. (2013) Tooth sizes in nonsyndromic hypodontia patients. The Angle Orthodontist, 83, 16-21.

Hamada R., Kondo S., and Wakatsuki E. (1997) Odontometrical analysis of Filipino dentition. The Journal of Showa University Dental Society, 17,197-207.

Hanihara K. (1976) Statistical and comparative studies of the Australian aboriginal dentition. The University Museum The University of Tokyo Bulletin, No.11, 1-57.

Hanihara K. (1977) Distances between Australian Aborigines and certain other populations based on dental measurements. Journal of Human Evolution, 6,403-418.

Hanihara K. (1979) Dental traits in Ainu, Australian Aborigines, and New World populations. In W.S. Laughline and A.B. Harper (Eds.), The first Americans, Origins, Affinities, and Adaptations (pp 125134). New York: Stuttgart.

Hanihara K. and Koizumi K. (1979) Sexing from crown diameters in the permanent teeth by discriminant function method. Journal of the Anthropological Society of Nippon, 87, 445-456. (In Japanese with English summary.)

Hanihara K. and Ueda H. (1979) Crown diameters in Japanese-American F1 hybrids. Ossa, 6, 105-114.

Hanihara T. (1989) Comparative studies of geographically isolated populations in Japan based on dental measurements. Journal of the Anthropological Society of Nippon, 97, 95-107.

Hanihara, T. (1990a) Affinities of the Philippine Negritos with Japanese and the Pacific populations based on dental measurements, The basic population in East Asia, I. Journal of the Anthropological Society of Nippon, 98, 13-27.

Hanihara T. (1990b) Studies on the affinities of Sakhalin Ainu based on dental characters, The basic populations in East Asia, III. Journal of the Anthropological Society of Nippon, 98, 425-437.

Harris E.F. and Nweeia M.T. (1980) Tooth size of Ticuna Indians, Colombia, with phenetic comparisons to other Amerindians. American Journal of Physical Anthropology, 53, 81-91. 
Harris E.F. and Bailit H.L. (1987) Odontometric comparisons among Solomon Islanders and other Oceanic peoples. In J.S. Friedlander and W.W Howells (Eds.), The Solomon Islands Project: A Long -Term Study of Health, Human Biology, and Culture Change (pp. 215-264). Cambridge: Oxford University Press.

Harris E.F. and Rathbun T.A. (1989) Small tooth sizes in a nineteenth century South Carolina plantation slave series. American Journal of Physical Anthropology, 78, 411-420.

Harris E.F., Potter R.H., and Lin J. (2001) Secular trend in tooth size in urban Chinese assessed from twogeneration family data. American Journal of Physical Anthropology, 115, 312-318.

Haeussler A.M., Irish J.D., Morris D.H., and Turner C.G. II (1989) Morphological and metrical comparison of San and Central Sotho dentitions from Southern Africa. American Journal of Physical Anthropology, 78, 115-122.

Hinton R.J., Smith M.O., and Smith F.H. (1980) Tooth size changes in Prehistoric Tennessee Indians. Human Biology, 52, 229-245.

Hosaka T. (1950) Study of the Chinese dentition. (Quoted by Sunaga, 1950). (In Japanese.)

Houghton P. (1978) Polynesian mandibles. Journal of Anatomy, 127, 251-260.

Inoue N., Takagi O., Kamegai T., and Ito G. (1983a) Studies on Tooth to Denture Base Discrepancy Consequent upon Human Evolution. II. Researches in Modern Japanese. 1. Investigation at Koromogawa Village, Iwate. Report of the study supported by a Grant-in-Aid for Co-operative Research of the Ministry of Education, Science and Culture, Japan.

Inoue N., Ito G., Inoue M., and Kamegai T. (1983b) Studies on Tooth to Denture Base Discrepancy Consequent upon Human Evolution. II. Researches in Modern Japanese. 2. Investigation at Kagoshima city, Kagoshima. Report of the study supported by a Grant-in-Aid for Co-operative Research of the Ministry of Education, Science and Culture, Japan.

Inoue N., Kamegai T., and Ito G. (1983c) Studies on Tooth to Denture Base Discrepancy Consequent upon Human Evolution. Researches in Modern Japanese. 3. Investigation at Yahaba town, Iwate. Report of the study supported by a Grant-in-Aid for Co-operative Research of the Ministry of Education, Science and Culture, Japan.

Inoue N., Ito G., Inoue M., and Kamegai T. (1983d) Studies on Tooth to Denture Base Discrepancy Consequent upon Human Evolution.II. Researches in Modern Japanese. 4. Investigation at Bohnotsu-Cho, Kagoshima. Report of the study supported by a Grant-in-Aid for Co-operative Research of the Ministry of Education, Science and Culture, Japan.
Inoue N., Ito G., Inoue M., and Kamegai T. (1983e) Studies on Tooth to Denture Base Discrepancy Consequent upon Human Evolution. II. Researches in Modern Japanese. 5. Investigation at Tokunoshima, Kagoshima. Report of the study supported by a Grant-in-Aid for Co-operative Research of the Ministry of Education, Science and Culture, Japan.

Inoue N., Kuwahara M., Ito G., and Inoue M., (1983f) Studies on Tooth to Denture Base Discrepancy Consequent upon Human Evolution. II. Researches in Modern Japanese. 6. Investigation at Nagoya city, Aichi. Report of the study supported by a Grantin-Aid for Co-operative Research of the Ministry of Education, Science and Culture, Japan.

Inoue N., Takahashi Y., Sakashita R., Wu M-L., Nozaki T., Chen C-W., Kamegai T., and Shiono K. (1992) Morphometrically and dental pathological studies on skulls from Yin-Shang Period. Journal of the Anthropological Society of Nippon, 100, 1-29.

İscan M.Y. (1989) Odontometric profile of a prehistoric Southeastern Florida population. American Journal of Physical Anthropology, 78, 3-8.

Iwagaki H. (1937) Statistical studies on the variation of teeth and arches. Monthly Dental Report, 17, 519552. (In Japanese with English summary.)

Jacob T. (1967) Racial identification of the Bronze age human dentitions from Bali, Indonesia. Journal of Dental Research, 46, 903-910.

Jacobson A. (1982) The dentition of the South African negro. Birmingham: U.A.B. School of Dentistry Publishers.

Janzer O. (1921) Die Zahne der Neu-Pommen. Vierteljhrsschr Zahnhlk, 43, 289-319 (in German)

Kaburagi M., Ishida H., Goto M., and Hanihara T. (2010) Comparative studies of the Ainu, their ancestors, and neighbors, assessment based on metric and nonmetric dental data. Anthropological Science, 118, 95-106.

Kamijyo Y. (1962) Anatomy of permanent dentition. Tokyo: Anatom Co. (In Japanese.)

Kanazawa E., Matsuno M., Nakabayashi T., Igarashi Y., and Nagai A. (1998) Tooth size of living peoples in Western and Eastern Micronesian populations. Anthropological Science, 106, 199-208.

Kanazawa E., Matsuno M., Sekiguchi H., Suzuki T., Satake T., Sasaki K., and Igarashi Y. (2000) Tooth size of people in Wabag, Papua New Guinea Highlanders and its comparison with Pacific peoples. Anthropological Science, 108, 169-181.

Kean M. R. and Houghton P. (1990) Polynesian face and dentition, Functional perspective. American Journal of Physical Anthropology, 82, 361-370.

Khalaf K., Robinson D.L., Elock C., Smith R.N., and Brook A.H. (2005) Tooth size in patients with supernumerary teeth and a control group measured 
by image analysis system. Archives of Oral Biology, 50, 243-248.

Kibi N. (1989) Physical affinity of the Pre- and Protohistoric Japanese of Kinki and Chugoku districts as viewed from dental measurements. Anthropological Reports, 48,1-25. (In Japanese.)

Kieser J.A. (1985a) An odontometric analysis of the early Griqua dentition. Anthropologischer Anzeiger, 43, 51-58.

Kieser J.A., Groeneveld H.T., and Preston C.B. (1985b) A metric analysis of the South African Caucasoid dentition. Journal of Dental Association (Assn) South Africa, 40, 121-125.

Kieser J.A., Groeneveld H.T., and Preston C.B. (1985c) An odontometric analysis of the Lengua Indians dentition. Human Biology, 57, 611-620.

Kieser J.A., Cameron N., and Groeneveld H.T. (1987) Evidence for a secular trend in the Negro dentition. Annals of Human Biology, 14, 517-532.

Kieser J.A. (1990) Human Adult Odontometrics. Cambridge: Cambridge University Press.

Kirch (1989) Human skeletal and dental remains from Lapita sites (1600-500BC) in the Mussau Islands, Melanesia. American Journal of Physical Anthropology, 79, 63-76.

Kirveskari P., Hansson H., Hedegard B., and Karlsson U. (1978) Crown size and hypodontia in the permanent dentition of Modern Skolt Lapps. American Journal of Physical Anthropology, 48, 107-112.

Kogiso T. (1982) A morphological study of sexual dimorphism in human masticatory apparatus. The Aichi-Gakuin Journal of Dental Science, 20, 229-267. (In Japanese with English summary.)

Koyoumdjisky-Kaye E., Zilberman Y., and Zeevi Z. (1976) A comparative study of tooth and dental arch dimensions in Jewish children of different ethnic descent. 1. Kurds and Yemenites. American Journal of Physical Anthropology, 44,437-444.

Koyoumdjisky-Kaye E., Zilberman Y., and Hazen O. (1977) A comparative study of tooth and dental arch dimensions in Circassian and Druse children. Zeitschrift für Morphologie und Anthropologie, 68, 298-306.

Koyoumdjisky-Kaye E., Steigam S., and Gudelevitch B. (1978) A comparative study of tooth and dental arch dimensions in Israel children of Cochin and North-African descent. Zeitschrift für Morphologie und Anthropologie, 69, 32-42.

Kudo K. (1985) A physical anthropological study of the teeth in the Bunun tribe of Taiwan aborigines. The Journal of the Kyushu Dental Society, 39,201-229. (In Japanese with English summary.)

Lavelle C.L.B., Ashton E.H., and Flinn R.M. (1970) Cusp pattern, tooth size and third molar agenesis in the human mandibular dentition. Archives Oral Biology, 15, 227-237.
Lavelle L.C.B. (1972) Maxillary and mandibular tooth size in different racial groups and in different occlusal categories. American Journal of Orthodontics, 61, 29-37.

Le Bot P. and Salmon D. (1977) Congenital defects of the upper lateral incisors (ULI), Condition and measurements of the other teeth, measurements of the superior arch, head and face. American Journal of Physical Anthropology, 46, 231-244.

Lee G.T.R. and Goose D.H. (1972) The dentition of Chinese living in Liverpool. Human Biology, 44,563-572.

Liao J.Y. (1984) Tooth size of Chinese in Taiwan. AichiGakuin Journal of Dental Science, 22, 111-140. (In Japanese with English summary.)

Liu K.L. (1977) Dental condition of two tribes of Taiwan Aborigines - Ami and Atayal. Journal of Dental Research, 56, 117-127.

Lukcas J.R. (1985) Tooth size variation in prehistoric India. American Anthropologist, 87, 811-825.

Macho G.A. and Moggi-Cecchi (1992) Reduction of maxillary molars in Homo sapiens sapiens, A different perspective. American Journal of Physical Anthropology, 87, 151-159.

Manabe Y., Kitagawa Y., Koyamada J., and Rokutanda A. (1996) Sexing from crown diameters in the permanent dentition by discriminant function analysis-An assessment in the Yami tribe, Taiwan aborigine-. Japanese Association for Oral Biology, 38, 713. (In Japanese with English summary.)

Matsumura H. (1989a) Geographical variation of dental measurements in the Jomon population. Journal of the Anthropological Society of Nippon, 97, 493512.

Matsumura H. (1990) Geographical variation of dental characteristics in the Japanese of the Protohistoric Kofun period. Journal of the Anthropological Society of Nippon, 98, 439-449.

Matsumura H. (1994) A microevolutional history of the Japanese people from a dental characteristics perspective. Anthropological Science, 102, 93-118.

Matsumura H. (1995a) Dental Characteristics of the Neolithic Remains from Jiangnan. In, Studies on the Human Skeletal Remains from Jiangnan, China. (Eds.) Yamaguchi B. and Xianghong H.), National Science Museum Monographs No. 10, 87-95.

Matsumura H. (1995b) Dental characteristics affinities of the Prehistoric to modern Japanese with the East Asians, American Natives and AustraloMelanesians. Anthropological Science, 103, 235-261.

Matsumura H. (1998) Native or Migrant Lineage? The Aeneolithic Yayoi people in Western and Eastern Japan -, Anthropological Science, 106, 1725. (Supplement).

Matsumura H., Cuong N.L., Thuy N.K., and Anezaki T. (2001) Dental morphology of the early Hoabinian, the Neolithic Da But and the Metal age 
Dong Son civilized peoples in Vietnam. Zeitschrift für Morphologie und Anthropologie, 83, 59-73.

Matsumura H. (2002) The possible origin of the Yayoi migrants based on the analysis of the dental characteristics. In T. Nakahashi and M. Li (Eds.), Kyusyu Ancient People in the Jiangnan Region (pp 61 -72). China: University Press, Fukuoka.

Matsumura H. and Hudson M.J. (2005) Dental perspectives on the population history of Southeast Asia. American Journal of Physical Anthropology, $127,182-209$.

Matsumura H., Oxenham M.F., Dodo Y., Domett K., Thuy N.K., Cuong N.L., Dung N.K., Huffer D., and Yamagata M. (2008) Morphometric affinity of the late Neolithic human remains from Man Bac, Ninh Binh Province, Vietnam, key skeletons with which to debate the 'two layer' hypothesis. Anthropological Science, 116, 135-148.

Matsumura H. and Dodo Y. (2009) Dental characteristics of Tohoku residents in Japan, implications for biological affinity with ancient Emishi. Anthropological Science, 117, 95-105.

Matsumura H., Ishida H., Amano T., Ono H., and Yoneda M. (2009) Biological affinities of Okhotskculture people with East Siberians and arctic people based on dental characteristics. Anthropological Science, 117, 121-132.

Matsumura H., Domett K.M., and O'reilly D.J.W. (2011) On the origin of pre-Angkorian peoples, perspectives from cranial and dental affinity of the human remains from Iron Agae Phum Snay, Cambodia. Anthropological Science, 119, 67-79.

Matsuno M. (1997) Dental anthropological study on tooth size in Fiji, Western Samoa and Kiribati. Nihon University Journal of Oral Science, 23, 33-52. (In Japanese with English summary.)

Mayhall J.T. (1979) The dental morphology of the Inuit of the Canadian Central Arctic. Ossa, 6, 199-218.

McKeown H.F., Robinson D.L., Elcock C., Al-Sharood M., and Brook A.H. (2002) Tooth dimensions in hypodontia patients, their unaffected relatives and a control group measured by a new image analysis system. European Journal of Orthodontics, 24, 131-141.

Mènard J. (1975) L'evolution des dents des Français. Bulletin Et Mèm. Society D'Anthropology, Paris, 2 , 45-59. (serie XIII).

Mijsberg W.A. (1931) On sexual differences in the teeth of Javanese. Koninklijke Akademie voor Wetenschap, 34, 1111-1115.

Miura F., Ichijyo T., Soma K., Kuroki T., Fukawa T., Maeda M., Tomita K., Hanada K., Ito A., Katagiri M., Jano A., Salas M.E., Pompa J.A., and Andrino J.A. (1989) Dental anthropological study of the Central American Indians. Journal of the Japanese Stomatological Society, 56, 409-428. (In Japanese with English summary.)
Miura F., Soma K., Kuroki T., Fukawa T., Ishida T., Ichijo T., Hanada K., Terada K., Fu M., Liu K., and Haung S. (1991) Dental anthropological study of Mongoloid in China. Journal of the Japanese Stomatological Society, 58, 566-579. (In Japanese with English summary.)

Miyabara T. (1915) An anthropological study of the masticatory system in the Japanese, (I) The teeth. The Dental Cosmos, 57, 739-749. (In Japanese with English summary.)

Mizoguchi Y. (1981) Variation units in the human permanent dentition. Bulletin of the National Science Museum, Tokyo Series D (Anthropology), 7, 29-39.

Mizoguchi Y. (1985) Shovelling, A Statistical Analysis of Its Morphology. The University Museum. University of Tokyo Press, Tokyo. Bulletin No. 26, 1-176.

Mizoguchi Y. (1986) Correlated asymmetries detected in the tooth crown diameters of human permanent teeth. Bulletin of the National Science Museum, Tokyo Series D (Anthropology), 12, 25-45.

Mizoguchi Y. (1988) A Statistical Analysis of Geographical Variation in Dental Size. A report of the Research Supported by a Grant-in-Aid for Scientific Research from the Ministry of Education, Science and Culture, Japan. Pp. 1-124.

Moorrees C.F.A. (1957) The Aleut Dentition. Cambridge: Harvard University Press.

Moorrees C.F.A., Thomsen S.O., Jensen E., and Yen P.K.J. (1957) Mesiodistal crown diameters of deciduous and permanent teeth. Journal of Dental Research, 36, 39-47.

Moorrees C.F.A. (1959) The Dentition of the Growing Child. Cambridge, Harvard University Press.

Nagamine Y. (1933) On the correlations between portions of dental morphology. Journal of the Nippon Dental Association, 26, 37-52. (In Japanese.)

Nagaoka K. and Kuwahara Y. (1993) Normal standards for various Roentgen cephalometric and cast model analysis in present day Japanese adults, Part I. The Journal of Japan Orthodontic Society, 52, 467-480. (In Japanese with English summary.)

Nagaoka T. and Hirata K. (2003) Geographical variation in Japanese tooth size in the Edo period. Anthropological Science (J-Series), 111, 143-154. (In Japanese with English summary.)

Nagaoka T. and Hirata K. (2006) Tooth size of the medieval period people of Japan. Anthropological Science, 114, 117-126.

Nagayama T. (1984) A physical anthropological study of the teeth in the tribe of Taiwan aborigines, Rukai. The Journal of the Kyushu Dental Society, 38, 971-1002. (In Japanese.)

Nakano M., Suzuki A., Murakami T., and Takahama Y. (1993) Tooth sizes and dentofacial forms of the orthodontic patients with tooth crowding. The Journal of Japan Orthodontic Society, 52, 104-118. (In Japanese with English summary.) 
Nelson C.T. (1938) The teeth of the Indians of Pecos Pueblo. American Journal of Physical Anthropology, 23, 261-293.

Okazaki K. (2005) Sex assessment of subadult skeletons based on tooth crown measurements: An examination on the interpopulational variation of sex differences and an application to excavated skeletons. Anthropological Science (J-Series), 113,139-159. (In Japanese with English summary.)

Ono A. (1957) Anthropological studies on the teeth of the Yayoi-age men from Mitsu, Kanazaki-gun, Saga-prefecture. Journal of the Anthropological Society of Nippon, 4, 423-462. (In Japanese.)

O'Rourke D.H., and Crawford M.H. (1980) Odontometric microdifferentiation of transplanted Maxican Indian populations, Cuanalan and Saltillo. American Journal of Physical Anthropology, 52, 421-434.

Otsubo J. (1957) A study on the tooth material in Japanese adults of normal occlusion, its relationship to coronal and basal arches. The Journal of Japan Orthodontic Society, 16, 36-46. (In Japanese.)

Oyamada J. (1992) Tooth crown size of Yayoi people in the North-West and the North of Kyushu. Journal of the Anthropological Society of Nippon, 100, 83100. (In Japanese with English summary.)

Oyamada J., Manabe Y., Kitagawa Y., Rokutanda A., and Nagashima S. (1995) Tooth size of the Protohistoric Kofun people in Southern Kyushu, Japan. Anthropological Science, 103, 49-60.

Ozaki T., Satake T., and Kanazawa E. (1987) Morphological significance of root length variability in comparison with other crown dimensions. I. Basic statistics and sex difference. Journal of Nihon University School of Dentistry, 29, 233-240.

Pedersen O.P. (1949) The East Greenland Eskimo Dentition. Copenhagen: CA Reitzel.

Perzigian A.J. (1975) Natural selection on the dentition of an Arikara population, American Journal of Physical Anthropology, 42, 63-69.

Perzigian A.J. (1976) The dentition of the Indian Knoll skeletal population odontometrics and cusp number. American Journal of Physical Anthropology, 44, 113-122.

Phenice T.W. (1969) An analysis of the human skeletal material from burial mounds in north central Kansas. University of Kansas Publications in Anthropology, Lawrence.

Potter R.H.Y., Alcazaren A.B., Herbosa F.M., and Tomaneng J. (1981) Dimensional characteristics of the Filipino dentition. American Journal of Physical Anthropology, 55, 33-42.

Prakash S., Kaul V., and Kanta S. (1979) Observations on the Bhutanese dentition. Human Biology, 51, 2330.
Radnzic D. (1987) Comparative study of mesiodistal crown diameters and arch dimensions between indigenous British and Pakistan immigrant populations. American Journal of Physical Anthropology, $72,479-483$.

Richardson E.R. and Malhotra S.K. (1975) Mesiodistal crown dimensions of the permanent dentition of American Negroes. American Journal of Orthodontics, 68, 157-64.

Rosenzweig K.A. and Zilberman Y. (1967) Dental Morphology of Jews from Yemen and Cochin. American Journal of Physical Anthropology, 26, 1522.

Rozenzweig K.A. and Zilberman Y. (1969) Dentition of Bedouin in Israel. II. Morphology. American Journal of Physical Anthropology, 31, 199-204.

Sakai T., Hanamura H., and Ohno N. (1971) Tooth size of the Pashtun and Tajik in Afghanistan. Journal of the Anthropological Society of Nippon, 79, 159-177. (In Japanese with English summary.)

Sanui Z. (1960) Dental anthropological studies of the Yayoi people in Doigahama remains, Yamaguchi District. Anthropological Association, 7, 861-884. (In Japanese with English summary.)

Sasaki M. (1982) A physical anthropological study of the teeth in the tribe of Taiwan aborigines, Paiwan. The Journal of the Kyushu Dental Society, 36, 433-467. (In Japanese with English summary.)

Sciulli P.W. (1979) Size and morphology of the permanent dentition in prehistoric Ohio Valley Amerindians. American Journal of Physical Anthropology, 50, 615-628.

Scott E.C. (1979) Increase in tooth size in prehistoric coastal Peru, 10000-1000 BC. American Journal of Physical Anthropology, 50, 251-258.

Seipel C.M., (1946) Variation in tooth position, a metric study of variation and adaptation in the deciduous and permanent dentitions. Swedish Dental Journal, 39, 1-176. (Supplement)

Selmer-Olsen R. (1949) An odontological study of the Norwegian Lapps. Skrift Norske Vidensk-Akademi, 3, 1-167.

Sharma J.C. (1983) Dental morphology and odontometry of the Tibetan immigrants. American Journal of Physical Anthropology, 61, 495-505.

Sharma J.C. (1985) Evolutional significance of dental morphology and odontometry. In V.R. Reddy (Ed.), Dental Anthropology, Application and Methods (pp 251-267). New Dehli: Inter-India Publications.

Smith P. (1972) Regional variation in tooth size and pathology in fossil hominids. American Journal of Physical Anthropology, 47, 459-466.

- Smith P. (1977) Selective pressures and dental evolution in Hominids. American Journal of Physical Anthropology, 47, 358-458. 
Smith P. (1979) Regional diversity in epipaleolithic populations. OSSA, 6, 243-250.

Smith P., Brown T., and Wood W.B. (1981) Tooth size and morphology in a recent Australian Aboriginal population from Broadbeach, South East Queensland. American Journal of Physical Anthropology, 55, 423-432.

Smith P. (1982) Dental reduction, selection or drift? In B. Kurtén (Ed.), Teeth: Form, Function and Evolution (pp. 366-381). New York: Columbia University Press.

Smith P. and Shegev M. (1988) The dentition of Nubians from Wadi Halfa, Sudan, an evolutionary perspective. Journal of the Dental Association of South Africa, 43, 539-541.

Snow C.E. (1974) Early Hawaiians: An Initial Study of Skeletal Remains from Mokapu, Oahu. Lexington: The University Press of Kentucky.

Sofaer J.A., Bailit H.L., and MacLean C.J. (1971) A developmental basis for differential tooth reduction during hominid evolution. Evolution, 25, 509-517.

Sunaga T. (1952) Morphology and anatomical studies in the dentition of Southern Chinese Fujian. The proceedings of Numata research institute, 4, 1-60. (In Japanese.)

Suzuki A. and Takahama Y. (1992) Tooth crown affinities among five populations from Akita, Tsushima, Tanegashima, Okinawa in Japan, and Middle Taiwan. Journal of the Anthropological Society of Nippon, 100, 171-182.

Suzuki A., Han B-J., Takahama Y., Son W-S., Itou K., and Matsuura S. (1994) Tooth crown affinities among South Koreans, Central Taiwanese, and Certain Japanese populations. Anthropological Science, 102, 271-283.

Suzuki M. and Sakai T. (1957) The living Sakhalin Ainu dentition. Anthropological Reports, Niigata University, 18, 303-346. (In Japanese with English summary.)

Suzuki N. (1993) Generational differences in size and morphology of tooth crowns in the young modern Japanese. Anthropological Science, 101, 405-429.

Suzuki T. (2007) Establishment of Edo people living in central Tohoku area based on tooth size. Tohoku University Dental Journal, 26, 81-100. (In Japanese.)

Swindler D.R., Drusini A.G., Cristino C., and Ranzano C. (1998) Comparison of molar crown size of precontact Easter Islanders with other Pacific groups. In, J.T. Mayhall and T. Heikkinen (Eds.), Dental Morphology (pp 63-73). Oulu University Press.

Swindler D.R. and Weisler M.I. (2000) Dental size and morphology of Precontact Marshall Islanders (Micronesia) compared with other Pacific islanders. Anthropological Science, 108, 261-282.

Takehisa S. (1957) An anthropological and morphological comparative study of American White teeth and Japanese teeth. Shikagakuhou 57, 1-41. (In Japanese.)

Takei T. (1990) An anthropological study on the tooth crown morphology in the Atayal tribe of Taiwan Aborigines, Comparative analysis between Atayal and some Asian-Pacific populations. Journal of the Anthropological Society of Nippon, 98, 337351. (In Japanese with English summary.)

Taverne P.P. (1980) Een Fysisch-Anthropologisch Onderzoek van de Gebitten van Vier Surinaamse Bevolkingsgroepen. Thesis, Rijksuiversiteit te Groningen. (In Dutch with English summary.)

Thilander B. (2009) Dentoalveolar development in subjects with normal occlusion. A longitudinal study between the ages of 5 and 31 years. European Journal of Orthodontics, 31, 109-120.

Thompson A.R. (2013) Odontometric determination of sex at Mound 72, Cahokia. American Journal of Physical Anthropology, 151, 408-419.

Thomsen S. (1955) Dental morphology and occlusion in the people of Tristan da Cunha. Results of the Norwegian Scientific Expedition to Tristan da Cunha, 1937-1938. No.25, 1-61.

Todaka Y., Oyamada J., Manabe Y., Kitagawa Y., Kato K., and Rokutanda A.(2003) The relationship between immigration and the prevalence of dental caries in the Yayoi people. Anthropological Science, 111, 265-292.

Tokitsu K. (1960) Anthropological studies on the palatum, the mandible and the teeth of the Atayal (Musha), Taichu prefecture, Formosa. Quarterly Journal of Anthropology, 7, 37-132. (Supplement), (In Japanese with English title.)

Toma T., Hanihara T., Sunakawa H., Haneji K., and Ishida H. (2007) Metric dental diversity of Ryukyu Islanders: a comparative study among Ryukyu and other Asian populations. Anthropological Science, 115, 119-131.

Townsend D.C. and Brown T. (1979) Tooth size characteristics of Australian Aborigines. Occasional Papers in Human Biology, 1, 17-38.

Townsend D.C. (1983) Tooth size in children and young adults with trisomy 21 (Down) syndrome. Archives of Oral Biology, 28, 159-166.

Townsend D.C. and Alvesalo L. (1985) Tooth size in 47, XYY males, evidence for a direct effect of the Y chromosome on growth. Australian Dental Journal, 30, 268-272.

Turner C..G. and Swindler D.R. (1978) The dentition of the New Britain West Nakanai Melanesians. VIII. People of the Pacific. American Journal of Physical Anthropology, 49, 361-372.

Tsuru H. (1978) An anthropological study on the physical traits of teeth in the inhabitants of Tanegashima Island. The Journal of the Kyushu Dental Society, 32, 227-260. (In Japanese with English summary.) 
Tsuzaki T. (1925) The dentition in the Taiwan Aborigi- y'Edynak G. (1989) Yugoslav Mesolithic dental reducnes. The Journal of Korean Medical Society, 55, 285304. (In Japanese.) tion. American Journal of Physical Anthropology, 78, 17-36.

Ueta H. (1984) Difference by sex in human tooth. The Journal of the Kyushu Dental Society, 38, 629-653. (In Japanese with English summary.)

Yamada E. (1931) The anthropological study of the Japanese teeth. Juzenkai Zasshi, 36, 469-586.

Yamada H. (1977) Factor analysis of human teeth, dental arch and palate. The Aichi-Gakuin Journal of Dental Science, 15, 267-287. (In Japanese with English summary.)

Yamada H., Kondo S., Sato A., and Kuwahara M. (1986a) Study of mesiodistal crown diameters in the deciduous and permanent dentitions in individuals. Journal of Growth, 25, 15-26.

Yamada H., Kondo S., Sato A., and Kuwahara M. (1986b) Study of buccolingual crown diameters in the deciduous and permanent dentitions in individuals. Journal of Growth, 25, 147-156.

Yamada H., Kogiso T., and Liao J-Y. (1986) Correlation matrices for the mesiodistal and buccolingual crown diameters of the Japanese and Chinese permanent teeth. Journal of the Anthropological Society of Nippon, 94, 473-479.

Yamada H., Kawamoto K., Sakai T., and Katayama K. (1988a) Inter-island variation in tooth size of the Cook Islanders, and their biological affinities with other Oceanic people. Journal of the Anthropological Society of Nippon, 96, 435-448.

Yamada H. and Kawamoto K. (1988b) The dentition of Cook Islanders. In, K. Katayama and A. Tagaya (Eds.), People of the Cook Islands - Past and Present. A report of the physical anthropological and linguistic research in the Cook Islands in 1985-1987 (pp. 143209), The Cook Islands Library and Museum Society Bulletin No. 5.

Yamada H. and Koshio Y. (2008) Mesiodistal crown diameters of anterior teeth in female orthodontic patients. Anthropological Science (Japanese Series), 116, 15-23. (In Japanese with English summary.)

Yamada H. and Tagaya A. (2018) Tooth size and its proportional variability in Japanese males with agenesis in permanent dentition. Anthropological Science, 126, 75-87.

Yamada K. (1984) A physical anthropological study of the teeth in the inhabitants of Gotoo Island in Nagasaki prefecture. The Journal of the Kyushu Dental Society, 38, 501-530. (In Japanese with English summary.)

Yamauchi K., Itou K., and Suematsu H. (1965) Standard for the measurements of plaster cast from Japanese young adults with normal occlusion. The Journal of Japan Orthodontic Society, 24, 1-7. (In Japanese with English summary.)

Yuen K.K-W., Tang E.L-K., and So L.L-Y. (1996) Relations between the mesiodistal crown diameters of the primary and permanent teeth of Hong Kong Chinese. Archives Oral Biology, 41, 1-7.

Van Reenen J.F. (1966) Dental features of a low-caries primitive population. Journal of Dental Research, 45,703-713.

Van Reenen J.F. (1982) The effects of attrition on tooth dimensions of San (Bushmen). In, B. Kurtén (Ed.), Teeth :Form, Function, and Evolution (pp. 182-203). New York: Columbia University Press.

Viciano J., Alemán I., D' Anastasio R., Capasso L., and Botella M.C. (2011) Odontometric sex discrimination in the Herculaneum sample (79 AD, Napes, Italy), with application to juveniles. American Journal of Physical Anthropology, 145, 97-106.

Viciano J., Lopez-Lazaro S, and Alemán I. (2013) Sex estimation based on deciduous and permanent dentition in a contemporary Spanish population. American Journal of Physical Anthropology, 152, 3143.

Wajeman G. and Levy G. (1979) Growth variations in the permanent teeth of modern man. Journal of Human Evolution, 8, 817-825.

Walimbe S.R. (1985) Crown dimensions among adult Muslim males of Ramapuram, Andhra Pradesh. Inter-India Publications, New Delhi.

Weidenreich F. (1937) The dentition of Sinanthropus pekinensis: A comparative odontography of the hominids. Palaeontologia Sinica, Series D, No. 1, Whole series, No. 101. Pp. 1-180. 